\title{
A RBGG mantém sua missão e se renova
}

\section{RBGG keeps its mission and is renewed}

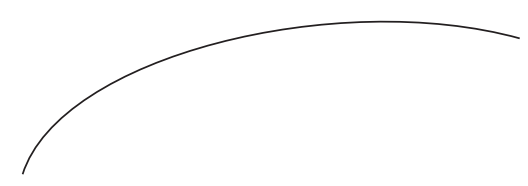

A RBGG continua sua missão de publicar a maior diversidade possível de temas e autores provenientes de todas as regiões de nosso país. Os temas abordados em diversos artigos deste número são: fragilidade, problemas de comunicação, atividade física, depressão, força muscular respiratória, estresse do cuidador, aspectos da qualidade de vida em idosos institucionalizados, dentre outros. São oriundos de pesquisas realizadas nos estados de São Paulo (UNICAMP, UNIFESP, UFSCarlos, UNESP), Amazonas (FIOCRUZ), Rio Grande do Sul (UFRS, UFSM, Un. Luterana, PUCRS), Minas Gerais (UFTM), Pará (UFPA), Paraná (Universidade Tuiuti do Paraná) e Santa Catarina (UFSC).

Neste número também é publicado um artigo que muito nos honrou. Trata-se de estudo de autoria de um grupo de pesquisadores da Universidade Federal do Rio Grande do Norte, que realiza uma análise da produção científica da Revista Brasileira de Geriatria e Gerontologia, através de uma revisão bibliométrica. Foi muito interessante para os editores ter conhecimento dessa avaliação tão rigorosa e crítica por parte de nossos leitores. Com sua publicação, esperamos inaugurar uma prática de avaliação da RBGG e que outros grupos de pesquisadores se animem a fazer análises semelhantes, pois é assim que a revista pode melhorar - recebendo críticas construtivas.

Outra novidade que estamos inaugurando neste número é uma seção temática sobre ambiência. Um grupo de pesquisadores da USP desenvolveu uma série de estudos sobre diversos aspectos da ambiência: espaço físico e comportamento; pertinência da noção de ambiências urbanas para o tema dos direitos dos idosos; espaços de lazer para a terceira idade; fatores ambientais e risco de quedas em idosos; e Gerontologia Ambiental. Estamos publicando esses artigos porque os editores consideraram a originalidade, o mérito científico e a pertinência desse tema tão importante para o desenvolvimento atual da Gerontologia em nosso país.

Portanto, como será possível verificar, estamos apresentando um número com muitas novidades. Com isso, esperamos manter o compromisso com a atualização de nosso público.

Boa leitura a todos! 